\title{
Impact of Samurdhi Program on Poverty Alleviation: An Empirical Investigation of Samurdhi Beneficiaries in Kopay DS Division in Jaffna district
}

\author{
Thavarasasingam, H.* and Balagobei, S. \\ Department of Financial Management, University of Jaffna, Sri Lanka \\ ${ }^{*}$ Hemaluxjini3@outlook.com
}

\begin{abstract}
The aim of this study is to investigate the impact of Samurdhi Program on poverty alleviation in Kopay DS Division. Two hundred questionnaires were issued to the Samurdhi beneficiaries of Kopay DS division, in Jaffna district, Sri Lanka Such as Kopay north (J/262),Irupalai South (J/257), Urelu $(\mathrm{J} / 267)$ and Urumpirai south $(\mathrm{J} / 265)$ divisions. Urelu $(\mathrm{J} / 267)$ and Urumpirai south $(\mathrm{J} / 265)$ divisions. Out of which, 177 questionnaires only could be collected. Hence, 177 Samurdhi beneficiary families were incorporated as samples. Correlation analysis and multiple linear regression analysis were used to analyze the data and examine the hypotheses by using the SPSS. The adjusted $\mathrm{R}^{2} 0.250$ for the model implies that approximately $25 \%$ of the total variance in poverty alleviation can be determined by all dimensions of Samurdhi program as the independent variable in this model. Further, the model reveals that the remaining $75 \%$ of variability was not explained in this model. In this study the findings revealed that there is a significant impact of Samurdhi program on poverty alleviation. Microcredit has a positive and significant impact on poverty alleviation. Livelihood activity has an insignificant impact on poverty alleviation. Welfare has a positive and significant impact on poverty alleviation. Based on the findings the researcher can conclude that Microcredit and welfare activity is effectively worked, and livelihood activity needs to improve itself.
\end{abstract}

Keywords: Income level, Livelihood activity, Micro credit, Poverty alleviation, Samurdhi Program, Welfare activity

\section{Introduction}

Poverty is a complex and multidimensional social phenomenon. It is widespread and includes a broad, worldwide population, from children to the elderly, and not excluding ethnic minorities. Poverty has been one of the biggest and most challenging problems and obstacles to human development, not only for under-developed or developing countries, but also for wealthier economies, the developed world. Hence, fighting poverty has become a global theme. According to Kesavarajah (2011) poverty is the lack of basic human needs, such as clean water, nutrition, health care, education, clothing and shelter, due to the inability to afford them, so poverty is a major threat to the world.

The year 2017 was declared as the year of poverty alleviation in Sri Lanka through the promotion of inclusive growth in keeping with the sustainable development goals of the United Nations. The Department of Samurdhi Development launched a people empowerment program last year targeting to empower 125,000 families selecting nine families from each GramaNiladhari division to achieve the target of no poverty by 2030 . Estimates reveal that around 6 percent of the population in the country yet live below the poverty line of earning less than one US\$ a day. Statistics also reveal that nearly half of the world's population lives on less than $\$ 2.50$ a day while over 1.3 billion live in extreme poverty living on less than $\$ 1.25$ a day.

Microfinance is one of the widely accepted instruments or poverty alleviation throughout the world. It has been used in Sri Lanka spanning for over several decades [Ganga et al., 2005]. The Micro Finance Institutions (MFIs) empowering the poor people because they are providing financial and non-financial services to enhance their living standard by providing the facilities for poverty alleviation, health nutrition, education and self-employment opportunities and helping to get capital and independent income and contribute economically to their family and society [Yogendrarajah, 2014]. In her study, she 
founds that, micro finance provides financial and non-financial services such as small loans, savings, micro leasing, micro-insurance and money transfer to assist the very poor people for their selfincome generating activities. Since independence, successive Sri Lankan Governments and NonGovernmental organization have launched several microfinance programs for poverty alleviation, income generation programs which include the establishment of Thrift and Credit Cooperative Societies, JanasaviyaProgram, SEEDS, Agro micro credit service, National Development Fund and recently the Samurdhi Program [Kumari, 2014].

As a developing country, Sri Lanka has a long history of social programs and food subsidies in particular. The major one of these is the Samurdhi program which was introduced in 1995.Its main goal was to reduce poverty in Sri Lanka through development based on public participation. However, few researchers argue that, Samurdhi as a social welfare Program, is suffering from inefficiency, miss-targeting, and lack of transference [Damayanthi, 2014, Kesavarajah, 2011, Thibbotuwawa et al., 2012].

Ismail et al. (2003) investigated that based on the program design, the key components of the Samurdhi include compulsory and voluntary savings, human resource development (productivity development training, training in accounting functions, training of executive committees and material resource development), establishment of Samurdhi Bank societies (responsible for the provision of credit), a community development program, labor-intensive peoples' projects, small industries development and social development Programs.

Furthermore, the most of the research has been done in the wide area of microfinance world-wide as well as in Sri Lankan wise, only few studies have been done in Jaffna District and no one has been highlighted on Samurdhi program, particularly in the Kopay Division. Hence, this study attempts to investigate how, as a social assistance program, the Samurdhi program impacts the poverty level. Mainly it focuses on the Kopay DS division in Jaffna District.

Numerous studies have been contributed to the empirical evidence on the broad area of Microfinance over the past years [Abdul-MajeedAlaro \& Alalubosa, 2019, Atiase \& Dzansi, 2019,
Gunatilaka \& Salih, 2017, Kim et al., 2018, Mahmood et al., 2014, Punjabi, 2010, Sayvaya \& Kyophilavong, 2015, Toindepi, 2016, Weerasinghe \& Dedunu, 2017]. Most of these studies were based on the data largely from other developing countries and little evidence from Sri Lanka [Damayanthi, 2014, Gunatilaka \& Salih, 2017, Kesavarajah, 2011, Kumari, 2014, Rizphy \& Jayasinghe-Mudalige, 2010]. Largely, in Sri Lanka empirical studies have been generated with a variety of institutions that related to the microfinance as explanatory variables which might potentially be associated for the poverty alleviation, increase in household income, women empowerment, and self-employment. These micro finance institutions are banks, nongovernmental micro finance institutions and some researchers have been done regarding Samurdhi Program and poverty in Sri Lanka, but it is very least in Jaffna particularly in Kopay DS division [Damayanthi, 2014, Gunatilaka \& Salih, 2017, Kesavarajah, 2011, Kumari, 2014, Rizphy \& Jayasinghe-Mudalige, 2010].

Furthermore, many researchers have accepted that microfinance is an important tool to alleviate poverty and enhance the living standard of poor people in the developing countries [AddaeKorankye, 2012, Morduch \& Haley, 2002]. As a developing country Sri Lanka has a long history of micro finance institutions, its services particularly to the poor, and there are a number of reasons that could have contributed for the enormous achievement in poverty reduction, the Samurdhi Program may be one of the major reasons for such achievement.

However there is limited Knowledge on the poverty alleviation through the microfinance programs of Samurdhi in Kopay DS Division. Since $39.47 \%$ of the total population of KopayDS division has fallen into the category of income is under Rs. 5000 per month as at December of 2018 [SHB, 2019]. Hence, there is a need to identify the poverty alleviation.

There is a contradiction whether the Samurdhi program is an effective vehicle to reduce poverty and there are number of criticisms of the Samurdhi program and its implementation. Therefore an evaluation of performance of the Samurdhi Banks is timely. Since this is the major program of governments towards poverty alleviation in Sri Lanka, there is a need to evaluate the program and its implications from time to time. 
Here researcher could note as per Damayanthi (2014) arguments, miss-targeting, lack of transparency, accountability, efficiency and effectiveness, equity and social justice as well as informed citizenry are some serious governance issues which make an impact on the Samurdhi ProgramIn this research context, researcher has been used poverty alleviation as dependent variable and Samurdhi program as independent variable

Thereby, researchers could take those problems and issues mentioned above as gaps. Hence, this study is willing to fill those research gaps and is formulating the following research question as a research problem. "How the Samurdhi program impacts on the poverty alleviation particularly in Kopay DS Division in Jaffna district, Sri Lanka?"

To formulate an answer to the above research question, the researcher prepares the following objective. It is to investigate the impact of Samurdhi program on poverty alleviation in Kopay DS Division. Further this study examines the impact of Samurdhi activities such as micro credit, livelihood and welfare on poverty alleviation individually.

Focusing on the importance of this issue there are numerous previous literature that have been done on poverty alleviation and Samurdhi program. Based on the empirical evidence the study develops the integration between the basic concepts such as poverty and Samurdhi program.

Gunatilaka et al. (1997) states that the word "Samurdhi" is derived from a local term meaning prosperity, and the program comprises a shortand long-term strategy. The short-term strategy involves poverty cushioning components, such as income support, social insurance and social development programs. The long-term strategy involves poverty alleviation through social mobilization, empowerment and integrated rural development. The program claims almost 1 percent of the gross domestic product (GDP) or roughly half of all welfare expenditures, excluding expenditures on education and health, and is the largest welfare program presently operating in the country [Glinskaya, 2000].

Many scholars have documented that the Samurdhi has various components in their studies. As explained by Glinskaya (2000) the Samurdhi program has three major components. The first is the provision of a consumption grant transfer (food stamp) to eligible households. This component claims 80 percent of the total Samurdhi budget. The second component of Samurdhi is a savings and credit program operated through so-called Samurdhi banks, and the loans were meant for entrepreneurial and business development. The third component is rehabilitation and development of community infrastructure through workfare and social (or human) development programs.

According to CPI (2017) the key components of the Samurdhi program includes the provision of a food stamp to the eligible households, accounting for approximately $80 \%$ of the total Samurdhi budget; A savings and credit program operate through the "Samurdhi banks", with loans destined for entrepreneurial and business development; the rehabilitation and development programs productivity development training, training in accounting functions, training of executive committees, and material resource development.

The Samurdhi program has three major components, consumption grant transfer (Food stamp), saving and credit program and rehabilitation and development of community infrastructure through workfare and social development programs [Hair et al., 1998].

Generally there is no exact definition for poverty as it is defined in different manner. Simply it can be defined as the inability of the people to attain a minimum standard of living. Those people who are unable to satisfy some of the basic needs such as food, shelter, clothes, sanitation, cleaning water, etc., are called poor. One billion people live on less than $\$ 1$ a day, the threshold defined by the international community as constituting extreme poverty, below which survival is questionable [Ahmed et al., 2007].

The World Bank's mission is to work for a world free of poverty. Punjabi (2010) states that more than subsidy the poor need credit lack of formal employment and poverty makes this strata of society non bankable as they do not have any credit history or documents of employment which forces them to borrow money from moneylenders, and landlords at an exorbitant rate of interest. The poorest people are the vulnerable people who are living without health nutrition, no access in education and their per capita income per day will be below 1 US\$ [Rathirani \& Semasinghe, 2015].

Sanjeewanie et al. (2012) focus on the multiple 


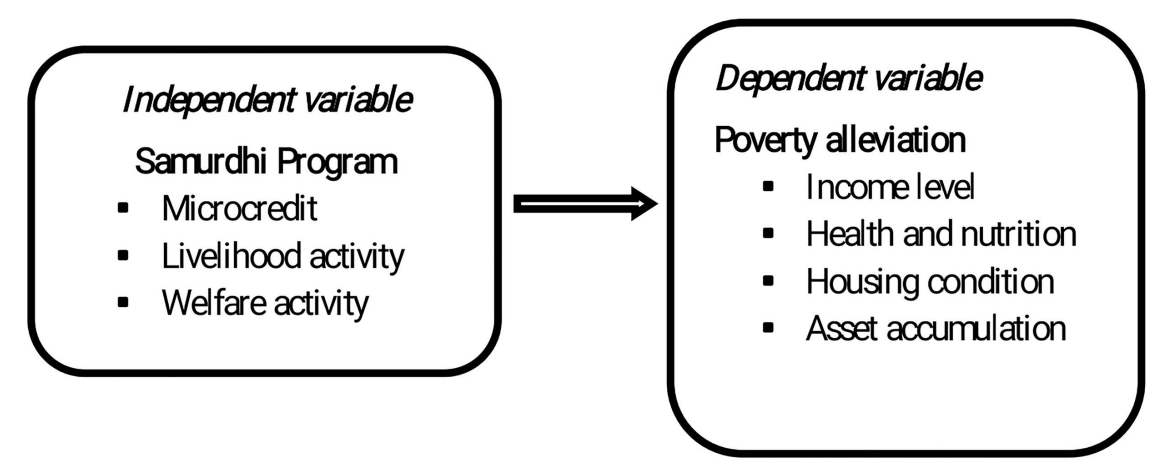

Figure 1: Conceptualization model

Source: Developed by researcher

dimensions of income, household assets and shelter, quality of employment, empowerment, dignity, physical safety, and psychological and subjective well being as multidimensional poverty indices in their study. Rizphy \& Jayasinghe-Mudalige (2010) examined the impact of Samurdhi microfinance program on poverty alleviation of farmers in Ampara District. They used 3 indexes, such as women empowerment, livelihood development and income generation and the sum of average value was taken as the value for the poverty alleviation index as the poverty alleviation cannot measure directly.

Based on the theoretical frame the conceptual model given in Figure 1 has been developed to represent the relationship between Samurdhi and poverty alleviation. The Samurdhi program consists of microcredit; livelihood activity and welfare activity whereas poverty alleviation is measured by income level, health nutrition, housing condition and asset accumulation.

The following model is expressed to investigate the impact of Samurdhi program on poverty alleviation based on the variables used in the study.

$$
\begin{aligned}
\text { Poverty alleviation }= & \beta_{0}+\beta_{1} M C+\beta_{2} L A \\
& +\beta_{3} W A+\epsilon_{i t}
\end{aligned}
$$

where $\beta_{0}, \beta_{1}, \beta_{2}$ and $\beta_{3}$ are regression coefficients, $M C$ is micro-credit, $W A$ is Welfare Activity, $L A$ is Livelihood Activity and $\epsilon_{i t}$ is the error term.

\section{Previous Studies and Hypothesis devel- opment}

Nowadays some debates are going on about the effectiveness of the Samurdhi program. Effectiveness of the Samurdhi Program has been a substantial national debate during the past decade, and much of this discussion has focused on the effectiveness of its targeting [Gunatilaka, 2010].

Rizphy \& Jayasinghe-Mudalige (2010) investigated the impact of Samurdhi microfinance program on poverty alleviation of farmers in Ampara District, and identify the constraints associated with Samurdhi micro credits to the poor. In this study, a questionnaire-based survey was used to collect the data from 60 farmers in the Addalaichanai Divisional Secretariat division. Their findings revealed that the poverty alleviation is significantly affected by the Samurdhi microfinance program by using multiple regression analysis. In addition, they suggested that the inspections of Samurdhi development officers should be made by the Samurdhi authority, to make better improvement through the Samurdhi microfinance program the efficient use of microcredit should be increased.

Gunatilaka \& Salih (2017) finds that Samurdhi's group savings and intra group credit component and Samurdhi bank program are functioning as important sources of emergency credit for beneficiaries. It also works better in rural areas than in urban areas. Also it is heavily reliant on the income transfer component and it has some constraints such as infrastructure bottlenecks and imperfections in the market for technology.

Sanjeewanie et al. (2012) carried out a study with an application of multidimensional poverty data to the policy needs to improve the effectiveness of the national social protection program, Samurdhi in Sri Lanka. For the purpose of this study, data from a pilot survey in the Badulla District were used to compare Samurdhi households with non Samurdhi households in 
relation to deprivation in multiple dimensions. They also argued that any program aiming to promote people out of poverty needs to be based on a good understanding of the nature of poverty among the target group. The findings of the study were that Samurdhi households are deprived in the dimensions of quality of employment, dignity and psychological and subjective well being, which have practical implications for the design and delivery of Samurdhi.

According to Thibbotuwawa et al. (2012) Samurdhi generates a significant impact on household welfare on income, consumption and education, despite the inefficiencies and political interferences associated with distribution of intended services. This study finds out the "Impact of microfinance on household welfare: Assessing the case on the Samurdhi Program in Sri Lanka". For the purpose of this study, Household Income \& Expenditure Survey (2006/07) data were used to estimate the impacts of 'Samurdhi' on the status of household income, health, education, and food and non-food consumption.

Gunawardane (2014) found out that the Samurdhi credit program plays a major role in empowering women in Sri Lanka. Specifically, the evidence suggests that access to credit for poor women has increased income in their families. Kumari (2014) investigated the impact of Microfinance on small entrepreneurships in Sri Lanka. Her findings revealed that the Samurdhi program is giving priority to develop the income generation programs in the area and it was creating few employment opportunities for village women.

Kesavarajah (2011) investigated poverty and Economic support in Sri Lanka. The objective of this context is to shed light on the effects of the government's Samurdhi expenditure on poverty reduction in Sri Lanka. She has reached the conclusion which confirms that the targeting outcomes of Samurdhi are inadequate and Samurdhi transfer program emerges as inefficient program, and also, she found that The Samurdhi Programappears to lack in the checks of accountability and transparency. Samurdhi officers are influenced by the local politicians. Politicization is embedded in the design and influences of both the selection of Samurdhi administrators and the selection of beneficiaries. Further, she has suggested that it is vital to redesign the Samurdhi program and increase the Samurdhi expenditure in a bid to reduce poverty and meet other development goals such as human development and improvement in productivity of workers through improved education and health.

According to Damayanthi (2014) Samurdhi Program is suffering from serious governance issues such as miss-targeting, lack of transparency, accountability, efficiency and effectiveness, equity and social justice as well as informed citizenry. She conducted this research to examine the governance issues in government's major poverty alleviation program - the Samurdhi program- in Sri Lanka for the purpose of this study, she used both primary and secondary data. Primary data was collected through questionnaire survey, key informant discussions and focus group discussions in selected eight districts. The quantitative data were analyzed using the simple statistical method and qualitative data and information were analyzed through descriptive methods.

In another study Damayanthi (2014) aimed to explore the ongoing issues of mal-targeting in the Samurdhi program and their effects on the actual poor and overall program effectiveness and why errors in targeting occurred in the safetynet and livelihood development components of the Samurdhi program in Sri Lanka, and the subsequent effects on the poor as well as on the program itself. Qualitative methods were used to collect and analyze data, and her findings revealed that, among a number of criticisms on program implementation is mal targeting or lack of proper targeting. Peoples' dependency mentality, politicization of the society, and outdated income level cut-offs were identified as major reasons for mal-targeting. Major outcomes of the maltargeting include disruptions to social harmony and decline in effectiveness of the program.

Damayanthi \& Champika (2014) attempted to evaluate the performance of Samurdhi Banks in poverty alleviation as well as for identifying the issues and difficulties faced by beneficiaries and officers in eight districts considering district poverty level. The findings show that, approximately 57 percent of the Bank customers' family income had increased due to the Samurdhi Programand it has also contributed 38 percent to increase of assets. As the authors have noted, fifty percent of the bank customers did not face any problem related to service delivery and getting services smoothly. But, among the weaknesses or issues 
faced by the customers, were that regulated account balance for loan was high, releasing the subsidy allowance was delayed, some of the officers did not provide efficient and effective services and that the maximum loan amount was not enough.

Ganga \& Sahan (2015) carried out a detailed analysis of Sri Lanka's social protection system and examines the relationship between social protection and labor market outcomes such as the labor force participation and employment status. The study revealed that the value of monthly cash transfers received under many social protection programs including the Samurdhi and PAMA remain low much lower compared to the national poverty line which identifies the minimum level of income required for a person per month to meet his/her basic needs. The study found out that the Samurdhi cash transfer program suffer from some targeting issues of inclusion and exclusion errors, lack of coordination of among programs implemented by different bodies and duplication or multiplicity of programs targeted towards certain vulnerable groups, Budgetary constraints and inequitable distribution of limited resources across programs and population segments. Moreover, the study stresses the need for improving 'targeting' in programs like Samurdhi and make better use of the limited resources available for social protection for the benefit of the 'most needy' groups.

Mahmood et al. (2014) explore the impact of microfinance loans on poverty reduction amongst women entrepreneurs in Pakistan. This exploratory study is based upon an empirical investigation of 123 semi structured interviews as well as in-depth, semi structured interviews with a subsample of ten women entrepreneurs who secured microfinance loans for their new or established enterprises. Emergent results show that access to finance is important for female entrepreneurs and helps them realize their potential as entrepreneurs.

Toindepi (2016) argues that business priorities of commercial microfinance providers differ significantly to those of development microfinance providers and this impact on the program design which means clients of each regardless of coming from the same target group may have different experiences. The microfinance concept evolved far beyond any single philosophical or ideological confinement that there is now need for formal recognition and acknowledgment that commercial and developmental microfinance paradigms are parallel models of approaches whose continuous evolution is less likely to converge in the near future, so should be treated separately.

Abdul-MajeedAlaro \& Alalubosa (2019) explore the option of Shar'ah-compliant microfinance as a viable alternative to many previous approaches adopted by the Nigerian State in tackling the menace of poverty in the land. The findings reveal that the suggested Shar'ah tools are viable and sustainable in lunching microfinance projects in the Nigerian context. Kim et al. (2018) show that technical efficiency (TE) of MFIs in Vietnam is considerably high with the average TE score and efficiency of scale being $85.5 \%$ and $94.7 \%$, respectively. Size, age, outreach, and market target of MFIs are found not to be the determinants of efficiency, while capital structure is.

Sayvaya \& Kyophilavong (2015) find that village development fund program has a positive impact on household income and expenditure but that the impact is statistically insignificant. Atiase \& Dzansi (2019) indicate that microfinance has contributed to employment generation and poverty reduction in the Greater Accra region of Ghana through the provision of microloans to necessity entrepreneurs to engage in various types of income-generating activities. However, necessity entrepreneurs faced loan inadequacy issues coupled with under-financing difficulties.

This study has formulated the following hypothesis as in line with the theory and previous studies in order to examine the relationship between the variables.

$\mathrm{H}_{1}$ : There is a significant impact of

Samurdhi Program on poverty alleviation.

$\mathrm{H}_{1 a}$ : There is a significant impact of microcredit on poverty alleviation.

$\mathrm{H}_{1 b}$ : There is a significant impact of livelihood on poverty alleviation.

$\mathrm{H}_{1 c}$ : There is a significant impact of welfare on poverty alleviation.

\section{Methods}

This study examines the impact of Samurdhi program on poverty alleviationin Kopay DS Division.It is based on a positivist paradigm and uses a deductive reasoning in establishing the causes and effects of a thus social phenomenon [Hussey \& Hussey, 1997]. The reasoning is deductive 
Table 1: Measurement for variables and concepts

\begin{tabular}{|c|c|c|c|}
\hline Concept & Variable & Indicator & Key references \\
\hline \multirow{4}{*}{$\begin{array}{l}\text { Samurdhi } \\
\text { Program }\end{array}$} & Microcredit & Size of loan & [Jayasuriya, 2007] \\
\hline & & Interest rate repayment & \\
\hline & Livelihood activity & $\begin{array}{l}\text { Employment opportunity } \\
\text { Training technical assistance }\end{array}$ & [Kumari, 2014] \\
\hline & Welfare activity & $\begin{array}{l}\text { Food stamp } \\
\text { Housing planning } \\
\text { Social welfare payments }\end{array}$ & $\begin{array}{l}\text { [Jayasuriya, 2007] } \\
\text { [Sharif, 2005] }\end{array}$ \\
\hline \multirow[t]{4}{*}{$\begin{array}{l}\text { Poverty } \\
\text { alleviation }\end{array}$} & Income level & $\begin{array}{l}\text { Income } \\
\text { Saving } \\
\text { Consumption }\end{array}$ & $\begin{array}{l}\text { [Jayasuriya, 2007] } \\
\text { [Damayanthi \& Champika, 2014] } \\
\text { [Rizphy \& Jayasinghe-Mudalige, } 2010\end{array}$ \\
\hline & Health and nutrition & $\begin{array}{l}\text { Food consumption } \\
\text { Medical facility }\end{array}$ & [Fasoranti, 2010] \\
\hline & Housing condition & $\begin{array}{l}\text { Water } \\
\text { Electricity } \\
\text { Assets }\end{array}$ & $\begin{array}{l}{[\text { Sanjeewanie et al., 2012] }} \\
\text { [Thibbotuwawa et al., 2012] }\end{array}$ \\
\hline & Asset accumulation & Household/ Business assets & $\begin{array}{l}\text { [Fatima \& Qayyam, 2016] } \\
\text { [Damayanthi \& Champika, 2014] }\end{array}$ \\
\hline
\end{tabular}

because the hypotheses are derived first, and then the related data will be collected later to confirm or negate these established hypotheses. Bryman \& Bell (2007) indicate that deductive approach is related to quantitative research that follows objectivism, ontological realism, and epistemological positivism. Gill \& Johnson (2002) argued that the development of a conceptual and theoretical structure prior to its testing through empirical observation is needed in a deductive research method. As a result, quantitative data was used as the evidence required for testing the hypotheses in this study.

The population for this study consists of all Samurdhi beneficiaries in Kopay DS Division in Jaffna District, Sri Lanka. Kopay DS division consists of sixteen villages subdivided into thirtyone GramaNiladhari and three Samurdhi Zones. Out of three Samurdhi Zones only one zone called Kopay Samurdhi bank was selected in which there are four GramaNiladhari (GN) such as Kopay north $(\mathrm{J} / 262)$ with the total of 427 Samurdhi beneficiaries, Irupalai South $(\mathrm{J} / 257)$ with the total of 510 Samurdhi beneficiaries, Urelu $(\mathrm{J} / 267)$ with the total of 579 Samurdhi beneficiaries and Urumpirai south $(\mathrm{J} / 265)$ with the total of 875 Samurdhi beneficiaries. So the total population of four GramaNiladhari consists of 2391 Samurd- hibeneficiaries. Finally200 Samurdhi beneficiaries in four GN divisions have been selected randomly. 200 Questionnaires were issued but the researcher could collect only 177 Questionnaires and 23 were not responded. Therefore, 177 samples could only be incorporated in this study.

In this study the primary data was gathered by using the questionnaire survey in Kopay DS division. The standard questionnaires with tested reliability were used. To examine the hypotheses of the study, the collected data was analyzed by using SPSS. The measurement of variables and concepts is indicated in Table 1.

\section{Results and Discussion}

Following paragraphs intend to answer the research question concerning "how the Samurdhi program impacts on the poverty alleviation particularly in Kopay DS Division in Jaffna District, Sri Lanka?" Firstly, a descriptive analysis of characteristics of the sample is presented. Secondly, the analysis focuses on the correlations between the variables. Thirdly, effects of Samurdhi program on poverty alleviation are examined to answer the research question. 
Table 2: Demographic characteristics of Samurdhi beneficiaries

\begin{tabular}{lcr}
\hline Demographic Characteristics & Frequency & Percentage \\
\hline Gender: & 4 & \\
Male & 173 & $2.3 \%$ \\
Female & & $97.7 \%$ \\
\hline Age: & 15 & \\
18-30 & 57 & $3.5 \%$ \\
$31-40$ & 54 & $30.5 \%$ \\
41-50 & 51 & $28.8 \%$ \\
Above 50 & & \\
Membership period in Samurdhi: & 16 & $9 \%$ \\
Below 1 year & 22 & $12.4 \%$ \\
2-3 year & 13 & $7.3 \%$ \\
4-5 year & 52 & $29.4 \%$ \\
5 year & 74 & $41.8 \%$ \\
Above 10 year & & \\
Educational qualification: 5 & 27 & $15.3 \%$ \\
Grade 5-10 & 73 & $41.2 \%$ \\
O/L & 58 & $32.8 \%$ \\
A/L & 19 & $10.7 \%$ \\
\hline Self-employment type: & & \\
Farmer/Agriculture & 27 & $15.3 \%$ \\
Cattle fostering & 27 & $15.3 \%$ \\
Sewing & 5 & $2.8 \%$ \\
Milk production & 5 & $2.8 \%$ \\
Petty ventures & 6 & $3.4 \%$ \\
Labour & 1 & $45.8 \%$ \\
Handicraft business & 14 & $0.6 \%$ \\
Other & 11 & $7.9 \%$ \\
None & & $6.2 \%$ \\
\hline
\end{tabular}

\section{Descriptive Analysis}

Descriptive statistics of the variables included in the study have been presented in the Table 2 .

As in line with the Table 2, it is quite clear that out of the total respondents investigated for this study, the overwhelming majority $(97.7 \%)$ of them are females whereas $2.3 \%$ are found to be males from 177 samples. It can be concluded that nowadays women are more involved than men in the Samurdhi bank activities.

Table 3: VIF Analysis

\begin{tabular}{lcc}
\hline & Tolerance & VIF \\
\hline Microcredit & 0.942 & 1.062 \\
Livelihood activity & 0.878 & 1.139 \\
Welfare activity & 0.905 & 1.105 \\
\hline
\end{tabular}

Dependent Variable: Poverty alleviation
Out of 177 respondents, the majority fall into the age group of $31-40$ years old which is $32.2 \%$. It is followed by $30.5 \%$ of the respondents who are aged $41-50$ years old, $28.8 \%$ of the respondents are aged above 50 years, and the rest of the $8.5 \%$ are fallen into 18-30. It can be concluded that the people from a family who are in the age group of 31-40 and 41-.50 are mostly involved into the Samurdhi program dealings.

This table entails that the majority of $41.8 \%$ of beneficiaries engaged into Samurdhi program was 10 years, $29.4 \%$ of the clients engaged in 5 years. $12.4 \%$ of the beneficiaries are engaged into Samurdhi program for 2-3 years and $9 \%$ of the beneficiaries are engaged in 1 year. Further the results revealed that the majority of the clients is in the category of grade 5-10. Moreover $32.8 \%$ had attained G.C.E O/L whereas $15.3 \%$ of the 
Table 4: Reliability Analysis

\begin{tabular}{lcc}
\hline Dimensions of variables & No. of dimensions & Cronbach's Alpha \\
\hline Microcredit & 7 & 0.723 \\
Livelihood activity & 5 & 0.698 \\
Welfare activity & 5 & 0.701 \\
Poverty Alleviation & 17 & 0.657 \\
\hline
\end{tabular}

beneficiaries had obtained the studies below grade 5 . It is noted that only $10.7 \%$ of beneficiaries had attended the A/L. Table 02 represents that the majority of $45.8 \%$ of total respondents is doing labour work and $15.3 \%$ of the beneficiaries are doing Cattle fostering and agriculture. Rest of the respondents are doing other work like sewing, petty ventures, and milk production. 11 beneficiaries amounted to $6.2 \%$ of respondents not doing any work.

\section{Multicollinearity Test}

In this study multicollinearity is measured using Variance Inflation Factor or Tolerance test. As in line with Table 3, all VIF values for variables are less than 10 then there can be concluded that there is no any issue on multi- collinearity.

\section{Reliability Test}

According to Hair et al. (1998) reliability is "extent to which a variable or set of variables is consistent in what it is intended to measure". The questionnaire on this study was circulated based on reliability by using SPSS software with Cronbach's alpha method. Thus the internal consistency of the Samurdhi program and poverty alleviation of this study was tested through Cronbach alpha coefficient.

Cronbach's alpha values were assessed for each variable with item-scales. The reliability of the test is reported in Table 4. The reliability of the measures was well above the minimum threshold of 0.60 in every case [Gliner \& Morgan, 2000]. Thus, it can be concluded that all of the measures were generally reliable.

\section{Correlation Analysis}

The correlation was made to examine the pattern or strength of the relationship between Samurdhi program and poverty alleviation of Samurdhi beneficiaries in Kopay DS Division in Jaffna district.

As per the results presented in the Table 5, microcredit is positively correlated with income level $(\mathrm{r}=0.451)$ and health \& nutrition $(\mathrm{r}=0.383)$ at 0.01 significance level while microcredit is positively significantly correlated with housing condition $(\mathrm{r}=0.284)$ and asset accumulation $(\mathrm{r}=0.277)$ at $1 \%$ significance level.

Livelihood activity is significantly positively linked with income level $(\mathrm{r}=0.244)$ and asset accumulation $(\mathrm{r}=0.281)$ at 0.01 significance level. Furthermore the welfare activity is positively significantly correlated with income level $(\mathrm{r}=0.202$, $\mathrm{p}=0.007)$ and asset accumulation $(\mathrm{r}=0.219$, $\mathrm{p}=0.003$ ) at 0.01 significant level whereas there is significant relationship between welfare activity and health and nutrition $(\mathrm{r}=0.152, \mathrm{p}=0.044)$ at 0.05 significance level.

\section{Regression Analysis}

The regression analysis was performed to evaluate the impact of Samurdhi program on poverty alleviation which is presented in Table 6 .

Based on Table 6 the value of the coefficient of determination (adjusted R-Squared) is 0.250 which shows that approximately $25 \%$ of the total variance in poverty alleviation can be determined by all dimensions of Samurdhi program as the independent variable in this model. Further, the model reveals that the remaining $75 \%$ of variability was not explained in this model. It is observed that the model is a good fit because the significant value (F-statistic) is less than 0.05.

Among the all three Samurdhi activities considered in the analysis, only two Samurdhi activities such as micro credit and welfare activities have a significant impact on poverty alleviation while there is not significant impact of livelihood activity on poverty alleviation.

In order to test the hypotheses, considering the probability of $t$ test of microcredit was less than 5\%. Hypothesis H1a stated that there is a significant impact of microcredit on poverty alleviation. The findings indicated that the mi- 
Table 5: Correlation Matrix

\begin{tabular}{lccccccc}
\hline & $(1)$ & $(2)$ & $(3)$ & $(4)$ & $(5)$ & $(6)$ & $(7)$ \\
\hline Micro credit (1) & 1 & & & & & & \\
& & & & & & \\
Livelihood activity (2) & $.226^{* *}$ & 1 & & & & & \\
& 0.002 & & & & & & \\
Welfare activity (3) & $.148^{*}$ & $.297^{* *}$ & 1 & & & \\
& 0.049 & 0 & & & & & \\
Income level(4) & $.451^{* *}$ & $.244^{* *}$ & $.202^{* *}$ & 1 & & & \\
& 0 & 0.001 & 0.007 & & & \\
Health \& nutrition(5) & $.383^{* *}$ & 0.089 & $.152^{*}$ & $.547^{* *}$ & 1 & & \\
& 0 & 0.24 & 0.044 & 0 & & & \\
Housing condition (6) & $.284^{* *}$ & -0.076 & 0.147 & 0.114 & $.517^{* *}$ & 1 & \\
& 0 & 0.314 & 0.051 & 0.13 & 0 & & \\
Asset accumulation (7) & $.277^{* *}$ & $.281^{* *}$ & $.219^{* *}$ & $.489^{* *}$ & $.293^{* *}$ & $.212^{* *}$ & 1 \\
& 0 & 0 & 0.003 & 0 & 0 & 0.005 & \\
\hline
\end{tabular}

${ }^{* *}$ Correlation is significant at the 0.01 level (2-tailed)

${ }^{*}$ Correlation is significant at the 0.05 level (2-tailed)

crocredit has a positive and significant impact on poverty alleviation. This finding was supported by a regression beta of 0.331 with $t$ statistics of 6.706 and the $\mathrm{p}$ value of 0.000 . This result is collaborated with Gunawardane (2014) and Jayasuriya (2007) and contradicts with Gunatilaka \& Salih (1999). The results support hypothesis H1a.

Hypothesis H1b stated that there is a significant impact of livelihood activity on poverty alleviation. Table 6 shows that there is insignificant impact of livelihood activity on poverty alleviation $(\mathrm{p}=$ $0.809>0.05)$. So Hypothesis H1b was not supported. This finding is contradicting with Kumari (2014).Meanwhile, the beta value for welfare activity is .144 and $\mathrm{p}$ value is less than 0.05 . Therefore the welfare activity has a significant impact on the poverty alleviation. Therefore hypothesis H1c was supported with findings. This is contradicting [Ganga \& Sahan, 2015].

To sum up the overall result, it can be concluded that the Samurdhi program significantly impacted on poverty alleviation ( $\mathrm{f}$ value $=20.570, \mathrm{P}=0.000$ ). This is consistent with the findings of Rizphy \& Jeyasinghe (2010) and Sanjeewanie et al. (2012).

\section{Conclusion}

This study mainly depicts the relationship between Samurdhi Program and poverty alleviation in Kopay DS Division. This study incorporated the Samurdhi Program as an independent variable which includes microcredit, livelihood activity and welfare activity. Poverty alleviation is incorporated as a dependent variable, which is measured by using Income level, Health and nutrition, Housing condition and Asset accumulation. The aim of this study is to investigate the impact of Samurdhi Program on Poverty Alleviation in Kopay DS Division.

Findings of the study can be stated as follows: there is a significant impact of Samurdhi program on poverty alleviation. Microcredit has positive and significant impact on poverty alleviation and livelihood activity has insignificant impact on poverty alleviation while welfare has positive and significant impact on poverty alleviation. Based on the findings the researcher can conclude that microcredit and welfare activity are effectively worked, and livelihood activity needs to improve itself.

\section{Limitations and Suggestions}

There are some limitations. First, there is a dearth of activities considered in the Samurdhi Programme in this study. A lot of activities are carried out under the Samurdhi Programme at village level. Second, the sample size is quite small and restricted to only 200 beneficiaries in the 4 GN divisions in a Samurdhi Zone in the Kopay Division. Third, many factors can affect the poverty alleviation, but in this context of the Samurdhi programme only few factors were considered. 
Table 6: Regression Analysis

\begin{tabular}{lcccc}
\hline & Coefficient & Std. Error & $\mathrm{t}$ & Significant value \\
\hline Constant & 1.845 & 0.216 & 8.532 & 0.000 \\
Microcredit & 0.331 & 0.049 & 6.706 & 0.000 \\
Livelihood activity & 0.011 & 0.047 & 0.243 & 0.809 \\
Welfare activity & 0.144 & 0.056 & 2.551 & 0.012 \\
\hline R-squared & & & & 0.263 \\
Adjusted R-squared & & & & 0.250 \\
F-statistic & & & & 20.570 \\
Prob (F-statistic) & & & & 0.000 \\
\hline
\end{tabular}

Dependent variable: Poverty alleviation

The study confirms that the Samurdhi Programme plays a vital role in reducing poverty and calls for the Government to adopt economic policies which aim at developing Samurdhi activities in order to help the poor population by making them exposed to better opportunities of employment and income growth, thereby achieving the goal of poverty reduction. The results found here suggest possible areas for future research also. The area would be the estimation of Samurdhi activities and poverty alleviation relationship using some other poverty indicator (i.e. head count ratio, other-income-based and welfare-based indicators). Apart from this, the study also does not take into consideration the individual issues of rural and urban poverty separately. A promising extension of this work would be to consider the rural-urban poverty reduction and its linkage with Samurdhi activities separately so that policies can be framed with an individual focus on rural as well as urban areas.

\section{References}

Abdul-MajeedAlaro,A. \& Alalubosa, A. (2019).Potential of Shar'ah compliant microfinance in alleviating poverty in Nigeria. International Journal of Islamic and Middle Eastern Finance and Management, 12(1), 115-129. DOI: 10.1108/imefm-01-2017-0021

Addae-Korankye, A. (2012). Microfinance: a tool for poverty reduction in developing countries. Journal of Business and Retail Management Research, 7(1), 138-149.

Ahmed, A. U., Hill, R. V., Smith, L. C., Wiesmann, D. M.,Frankenberger, T., Gulati, K., \& Yohannes, Y. (2007). The world's most deprived: Characteristics and causes of extreme poverty and hunger, 43. DOI: $10.2499 / 0896297705$

Atiase, V. \& Dzansi, D. (2019). Microfinance and Necessity Entrepreneurship: The Ghanaian Experience. Societal Entrepreneurship and Competitiveness, 155-170. DOI: 10.1108/978-183867-471-720191011

Bryman, A. \& Bell, E. (2007). Business Research Methods 2nd ed., New York: Oxford.

Centre for Public Impact (2017). The SamurdhiProgramme in Sri Lanka. Asia \&Ocenia.

Damayanthi, M. N. (2014). Good governance and poverty alleviation programmes in Sri Lanka: special reference on Samurdhiprogramme, 47(1), 43-64.

Damayanthi, M. N., \& Champika, P. J. (2014). An Evaluation of Samurdhi Banks in Poverty Alleviation.

Fasoranti, M. M. (2010). The influence of microcredit on poverty alleviation among rural dwellers: A case study of Akoko North West Local Government Area of Ondo State. African Journal of Business Management, 4(8), 14381446. DOI: $10.3923 /$ jeth.2010.1.8

Fatima, K., \& Qayyum, A. (2016).Remittances and Asset Accumulation of Household in Pakistan.

Ganga, T., \& Sahan, J. (2015). Social Protection in Sri Lanka: Current Status and Effect on Labor Market Outcomes.Sarnet working paper no. 3 . 
Ganga, T., Upali, W., \& Kumara, T. (2005). Microfinance for Poverty Alleviation in Sri Lanka: A Household Level Analysis of Outreach and Impact on Poverty. Institute of Policy Studies of Sri Lanka. DOI: 10.4038/sljss.v40i1.7501

Gill, J. \& Johnson, P. (2002). Research Methods for Managers, Sage Publications Limited

Glinskaya, E. (2000). An Empirical Evaluation of Samurdhi Program: Background paper for Sri Lanka Poverty Assessment. Report Number 22535-CE. World Bank draft report.

Gliner, J. A. \& Morgan, G. A. (2000). Research methods in applied settings: An integrated approach to design and analysis. Mahwah, NJ, US: Lawrence Erlbaum Associates Publishers. DOI: $10.4324 / 9781410605337$

Gunatilaka, R. (2010, March). Safety Nets for Social Protection: Sri Lanka's SamurdhiProgramme. In Research Meeting on Social Protection Policies in South Asia.

Gunatilaka, R., \& Salih, R. (1999). How successful is Samurdhi's savings and credit programme in reaching the poor in Sri Lanka? Institute of Policy Studies Victoria University of Welling, 3.

Gunatilaka, R., Perera, R., Salih, R., \& De Silva, C. (1997). The SamurdhiProgramme: A Preliminary Evaluation. Institute of Policy Studies, Colombo, Sri Lanka.

Gunatilaka, R., Salih, R. (2017). How successful is Samurdhi's savings and credit programme in reaching the poor in Sri Lanka? Institute of policy studies.

Gunawardane, D. (2014). Samurdhi Credit Programme, poverty reduction and empowering women in Sri Lanka. Rajarata University of Sri Lanka,IRSYRU, 286-288.

Hair, J. F., Black, W. C., Babin, B. J., Anderson, R. E., \& Tatham, R. L. (1998). Multivariate data analysis (Vol. 5): Prentice hall Upper Saddle River, NJ.

Hussey, J., \& Hussey, R. (1997). Business Research - A practical guide for undergraduate and postgraduate students. London: Macmillan Press Ltd. DOI: 10.1007/978-1-349-25262-6
Ismail, S. J., Immink, M. D. C., Immink, M. D., Mazar, I., \& Nantel, G. (2003). Community-based food and nutrition programmes: what makes them successful: A review and analysis of experience.Food and Agriculture Organization of the United Nations. DOI: 10.18356/bd7db620-en

Jayasuriya, P. K. (2007). lmpact of the Micro Finance on Poverty Alleviation in Sri Lanka: Special Reference to SammurdhiProgramme, Proceedings of the Annual Research Symposium, Faculty of Graduate Studies, University of Kelaniya, 55 .

Kesavarajah, M. (2011). Poverty and economic support in Sri Lanka: The case of Samurdhiprogramme. Retrived from http://www.iiirr. ucalgary.ca/files/iiirr/26.pdf.

Kim, N., Long, L. \& Sang, N. (2018). Evaluating the Efficiency of Microfinance Institutions in Vietnam and the Impact of this Efficiency on Poverty Reduction. Global Tensions in Financial Markets, 34, 167-181. DOI: 10.1108/s0196382120170000034008

Kumari, P. J.A. (2014). The impact of microfinance on small entrepreneurships in Sri Lanka: BIOINFO Business Economics, 2(1), 06-09. DOI: $10.9735 / 2249-1775$

Mahmood, S., Hussain, J. \& Z. Matlay, H. (2014).Optimal microfinance loan size and poverty reduction amongst female entrepreneurs in Pakistan. Journal of Small Business and Enterprise Development, 21(2), 231-249 DOI: 10.1108/jsbed-03-2014-0043

Morduch, J., \& Haley, B. (2002).Analysis of the Effects of Microfinance on Poverty Reduction. NYU Wagner Working Paper No. 1014.The Canadian International Development Agency, Canada.

Punjabi, N. M. (2010). Future Trends in Microfinance Sector in India. In Paper Presentation at UGC Sponsored Two Day State Level Multidisciplinary Seminar on Microfinance 'A tool for Women Empowerment \& Poverty Alleviation', HR College of Commerce \& Economics, Mumbai.

Rathirani, Y., \& Semasinghe, D. M. (2015). Factors determining the women empowerment 
through microfinance: An empirical study in Sri Lanka. International Journal of Social, Behavioural, Educational, Economic, Business and Industrial Engineering, 9(5), 2328-2185.

Rizphy, M., \& Jayasinghe-Mudalige, U. K. (2010). Impact of Samurdhi Microfinance Programme on Poverty Alleviation: A Case Study of Paddy Farmers in the Ampara District. In Proceedings of 10th Agricultural Research Symposium, 373, 376.

Sanjeewanie, K. H., Silva, N. D., \& Shivakumaran, S. (2012). Multi-dimensional poverty among Samurdhi welfare recipients in Badulla district, Sri Lanka (PMMA Working Paper, 2012-03). https://nbn-resolving.org/urn:nbn:de:0168ssoar-360886 DOI: 10.2139/ssrn.2348183

Sayvaya, I. \& Kyophilavong, P. (2015). Does microfinance reduce poverty in Lao PDR?.International Journal of Development Issues. 14 (3), 215-230. DOI: 10.1108/ijdi-102014-0072

Sharif, I. (2005). Social interactions, election goals and poverty reduction: evidence from an anti-poverty program in Sri Lanka. National Graduate Institute for Policy Studies.
Statistical Handbook.(2019). DS office Kopay.

Thibbotuwawa, R. M. M. I., Printhika, B. L. D. S., Jayasinghe-Mudalige, U. K., \& Udugama, J. M. M. (2012). Impact of Microfinance on Household Welfare: Assessing the Case of Samurdhi Program in Sri Lanka. In 56th Annual Australian Agricultural and Resource Economics Society (AARES) National Conference, Fremantle, February, 7-10.

Toindepi, J. (2016). Investigating a best practice model of microfinance for poverty alleviation. International Journal of Social Economics, 43(4), 346-362. DOI: 10.1108/ijse-05-2014-0091

Weerasinghe, I. M. S., \& Dedunu, H. H. (2017). Impact of microfinance on living standard with reference to microfinance holders in Kurunegala District. International Journal of Business Marketing and management (IJBMM), 2, 1623.

Yogendrarajah, R. (2014). Impacts of Micro Finance Institutions: Issues and ConceptsAn Empirical Study on Sri Lankan Context. Journal of Business \& Management, 2(4), 302315. DOI: $10.2139 /$ ssrn. 2505432 